\title{
WIEDZA PACJENTÓW PO OPERACYJNYM LECZENIU DYSKOPATII LĘDŹWIOWEJ NA TEMAT SAMOOPIEKI
}

\section{LEVEL OF KNOWLEDGE REGARDING SELF-CARE IN PATIENTS UNDERGOING LUMBAR DISCOPATHY SURGERY}

\author{
Jolanta Karakuła ${ }^{1}$, Beata Babiarczyk ${ }^{2}$ \\ ${ }^{1}$ Wojewódzki Szpital Specjalistyczny Nr 2 w Jastrzębiu-Zdroju \\ ${ }^{2}$ Wydział Nauk o Zdrowiu \\ Akademia Techniczno-Humanistyczna w Bielsku-Białej
}

DOI: https://doi.org/10.20883/pielpol.2017.50

\section{STRESZCZENIE}

Wstęp i cel. Najczęstszą postacią choroby zwyrodnieniowej kręgosłupa jest dyskopatia. Jeżeli leczenie zachowawcze nie przynosi zamierzonego efektu lub występuje silny ból z symptomami ucisku na korzeń i potwierdzeniem w badaniach radiologicznych, wskazana jest interwencja chirurgiczna. Celem badania była ocena poziomu wiedzy pacjentów po operacyjnym leczeniu dyskopatii lędźwiowej na temat samoopieki.

Materiał i metody. W badaniu uczestniczyło 78 pacjentów oddziału neurochirurgii, będących po zabiegu operacyjnym dyskopatii lędźwiowej. Zastosowano metodę sondażu diagnostycznego, technikę ankiety. Narzędziem badawczym była ankieta własnej konstrukcji.

Wyniki. Prawie wszyscy badani byli operowani po raz pierwszy. Zdecydowana większość otrzymała informacje na temat samoopieki od personelu medycznego, najczęściej po zabiegu. Prawie połowa badanych uważa, że wie, co robić, aby uniknąć nawrotów dyskopatii, większość wskazywała prawidłowe zachowania zdrowotne w ramach wybranych elementów profilaktyki wtórnej po zabiegu operacyjnym. Wiedza ogólna była istotnie statystycznie zdeterminowana przez zmienne: „rodzaj wykonywanej pracy” $(p=0,019)$ oraz „subiektywna ocena wiedzy badanych na temat samoopieki" ( $p<0,0001)$. Wykształcenie wpływało istotnie na posiadanie obaw i lęku o sprawność fizyczną po operacji $(p<$ 0,001 ). Nikt nie negował swojego zadowolenia $z$ wykonanego zabiegu operacyjnego.

Wnioski. Badani, pomimo prowadzonej na oddziale neurochirurgii edukacji zdrowotnej, nadal wykazują braki w świadomości prawidłowych zachowań, przestrzeganie których chroni przed nawrotem dyskopatii lędźwiowej.

SŁOWAKLUCZOWE: dyskopatialędźwiowa, leczenie operacyjne, samoopieka, edukacja zdrowotna.

\section{Wprowadzenie}

Dyskopatia lędźwiowa to najczęstsza choroba kręgosłupa, przebiegająca z uszkodzeniem struktury układu nerwowego. Zarówno sama choroba, jak i towarzy-

\begin{abstract}
Introduction and aim. Discopathy is the most common form of degenerative disc disease. If conservative treatment does not help or the pain gets worse with symptoms of compression on the spinal nerve roots, surgery is indicated. The aim of the study was to assess the level of knowledge in patients after discopathy surgery on self-care.

Material and methods. The study included 78 patients of Neurosurgery after their discopathy surgery. The study employed a questionnaire method with a questionnaire of own design as a research tool.

Results. Almost all respondents were operated for the first time. The vast majority received information about self-care from the medical staff, usually after surgery. Nearly half of them think they know how to avoid the recurrence of discopathy. The majority indicated the correct health behaviors in selected elements of the secondary disease prevention. General knowledge was significantly determined by the variable 'type of work' $(p=0.019)$ and 'subjective assessment of knowledge about self-care' $(p<$ 0.0001). Education significantly affects having concerns and fear of physical activity after surgery $(p<0.001)$. No one denied his/ her satisfaction with performed surgery.

Conclusions. Respondents, despite the health education conducted at the Neurosurgery ward, continue to show deficiencies in health behaviors, compliance with which prevents recurrence of discopathy.
\end{abstract}

KEYWORDS: lumbar discopathy, surgery, self-care, health education.

szące jej objawy stanowią narastający problem społeczny. Według danych GUS zespoły bólowe dolnego odcinka kręgosłupa są jednym z sześciu najczęściej zgłaszanych przez Polaków problemów zdrowotnych; 
uskarża się na nie 21,2\% dorosłych mężczyzn i 28,4\% kobiet [1]. Następstwem tych zespołów bólowych jest spadek wydolności fizycznej, społecznej i zawodowej, co często ma wpływ na niską samoocenę i poczucie złej jakości życia. To z kolei prowadzić może do powstawania problemów natury psychicznej, z objawami depresji, zaburzeniami snu, napadami lękowymi i poczuciem utraty kontroli nad swoją sytuacją życiową. Absencja chorobowa i wysokie koszty leczenia określają natomiast zespoły bólowe kręgosłupa jako duży problem ekonomiczny [2-4]. Wśród czynników ryzyka wystąpienia dyskopatii lędźwiowej można wymienić przebyty uraz lub długo trwające urazy przeciążeniowe, podnoszenie ciężarów powyżej 10\% wagi własnej, w nieprawidłowy sposób, czynniki zawodowe, np. praca w jednostajnej, niekorzystnej pozycji ciała, i otyłość, szczególnie w przebiegu cukrzycy [5, 6]. Głównym objawem dyskopatii lędźwiowej jest ból w tej okolicy, w rzucie kręgosłupa i okolicy przykręgosłupowej oraz promieniowanie bólu w stronę miednicy i kończyn dolnych. Kolejnymi symptomami są zaburzenia czucia, najczęściej powierzchniowego, w postaci parestezji, ale $\mathrm{i}$ jego osłabienia, zgodnie z obszarem unerwienia uszkodzonego korzenia nerwowego. W przypadku długo trwającego uszkodzenia funkcji i ucisku korzeni nerwowych może dojść do zniesienia odruchów okostno-ścięgnistych oraz niedowładu mięśni, objawiających się zmniejszeniem obwodu zajętej kończyny. Objawy mogą spowodować asymetrię zrównoważonej postawy ciała [7, 8]. Niezmiernie istotne jest wczesne rozpoznanie i leczenie choroby, która - nieleczona - może prowadzić do pogorszenia się ogólnego stanu zdrowia chorego, a nawet do trwałego inwalidztwa [9]. W początkowym etapie stosuje się terapię zachowawczą z wykorzystaniem leczenia przeciwbólowego, przeciwzapalnego i leków zmniejszających napięcie mięśniowe. W przypadku braku poprawy stosuje się fizykoterapię prądami, polem magnetycznym, laseroterapię, krioterapię, rehabilitację, masaż oraz miejscowe blokady niwelujące dolegliwości bólowe. Optymalne wyniki można uzyskać, stosując kompleksową terapię usprawniającą, która oprócz usunięcia bólu, wzmocni mięśnie tułowia, ustabilizuje kręgosłup oraz wykształci prawidłową postawę [10, 11]. Jeżeli takie leczenie nie przynosi zamierzonego efektu lub występuje silny ból z symptomami ucisku na korzeń nerwowy i potwierdzeniem w badaniach radiologicznych, wskazana jest interwencja chirurgiczna [12-16].

W powrocie do zdrowia istotna jest przede wszystkim fachowa i rzetelna pomoc medyczna. Aby jednak zastosowane leczenie przyniosło oczekiwany skutek, ważna jest edukacja pacjenta i pomoc w dążeniu do prawidłowej samoopieki. Samoopieka po zabiegu operacyjnym dyskopatii lędźwiowej to nic innego jak kształtowanie prawidłowych nawyków zdrowotnych, przez unikanie zachowań niekorzystnych, stosowanie odpowiednio do wieku i stanu zdrowia zbilansowanej diety, utrzymanie prawidłowego BMI, uprawianie sportów zgodnie z zaleceniami lekarza i rehabilitanta. Pacjent dobrze wyedukowany w kwestii samoopieki to pacjent uświadomiony, potrafiący zadawać pytania na temat swojej choroby i podejmujący świadome decyzje w kwestii rekonwalescencji czy leczenia przeciwbólowego.

Celem głównym niniejszej pracy była ocena wiedzy pacjentów po zabiegach operacyjnych dyskopatii lędźwiowej na temat wybranych elementów samoopieki.

\section{Materiał i metody}

Badania przeprowadzono w Wojewódzkim Szpitalu Specjalistycznym Nr 2 w Jastrzębiu-Zdroju, na oddziale neurochirurgii, w okresie od stycznia do marca 2016 roku. Na przeprowadzenie badań uzyskano zgodę Dyrektora ds. Lecznictwa ww. szpitala. Kryteriami włączenia pacjentów do badań były: wiek powyżej 18 lat, hospitalizacja i leczenie operacyjne dyskopatii lędźwiowej w okresie badawczym oraz wyrażenie świadomej zgody na wypełnienie ankiety. Uczestnictwo w badaniu było dobrowolne i anonimowe, o czym każdy z badanych był poinformowany przed jego rozpoczęciem. W badanym okresie na oddziale neurochirurgii wykonano 100 zabiegów operacyjnych dyskopatii lędźwiowej. Każda z operowanych osób wyraziła zgodę i otrzymała ankietę. Zwrotnie uzyskano 80 ankiet. Do celów statystycznych wykorzystano 78 prawidłowo wypełnionych ankiet. Charakterystykę grupy badanej z uwzględnieniem płci przedstawiono w tabeli 1.

Tabela 1. Charakterystyka cech socjodemograficznych badanych z uwzględnieniem płci

Table 1. Socio-demographic characteristics of the researched group by sex

\begin{tabular}{|c|c|c|c|c|c|c|c|}
\hline \multirow{3}{*}{\multicolumn{2}{|c|}{$\begin{array}{l}\text { Zmienne socjodemograficzne/ } \\
\text { Socio-demographic variables }\end{array}$}} & \multirow{2}{*}{\multicolumn{2}{|c|}{$\begin{array}{l}\text { Ogółem/ } \\
\text { Total } \\
\text { N=78 }\end{array}$}} & \multicolumn{4}{|c|}{ Płeć/Sex } \\
\hline & & & & \multicolumn{2}{|c|}{$\begin{array}{c}\text { mężczyźni/ } \\
\text { males } \\
\mathrm{N}=37\end{array}$} & \multicolumn{2}{|c|}{$\begin{array}{c}\text { kobiety/ } \\
\text { females } \\
\mathrm{N}=41\end{array}$} \\
\hline & & $n$ & $\%$ & $\mathrm{n}$ & $\%$ & $\mathrm{n}$ & $\%$ \\
\hline \multirow{5}{*}{$\begin{array}{l}\text { Wiek/ } \\
\text { Age }\end{array}$} & $\begin{array}{l}\text { poniżej } 30 \text { lat/ } \\
\text { under } 30 \text { years }\end{array}$ & 9 & 11,5 & 7 & 18,9 & 2 & 4,9 \\
\hline & 30-39 & 23 & 29,5 & 12 & 32,4 & 11 & 26,8 \\
\hline & $40-49$ & 18 & 23,1 & 7 & 18,9 & 11 & 26,8 \\
\hline & $50-59$ & 12 & 15,4 & 4 & 10,8 & 8 & 19,5 \\
\hline & $\begin{array}{l}60 \text { lat i więcej/ } \\
\text { over } 60 \text { years }\end{array}$ & 16 & 20,5 & 7 & 18,9 & 9 & 22,0 \\
\hline \multirow{2}{*}{$\begin{array}{l}\text { Stan cywilny/ } \\
\text { Marital status }\end{array}$} & $\begin{array}{l}\text { wolny/ } \\
\text { single }\end{array}$ & 18 & 23,1 & 8 & 21,6 & 10 & 24,4 \\
\hline & $\begin{array}{l}\text { w związku/ } \\
\text { in a relationship }\end{array}$ & 60 & 76,9 & 29 & 78,4 & 31 & 75,6 \\
\hline \multirow{5}{*}{$\begin{array}{c}\text { Wykształce- } \\
\text { nie/ } \\
\text { Education }\end{array}$} & $\begin{array}{l}\text { podstawowe/ } \\
\text { primary school }\end{array}$ & 4 & 5,1 & 1 & 2,7 & 3 & 7,3 \\
\hline & $\begin{array}{c}\text { zawodowe / } \\
\text { vocational school }\end{array}$ & 25 & 32,0 & 17 & 45,9 & 8 & 19,5 \\
\hline & $\begin{array}{l}\text { średnie/ } \\
\text { college }\end{array}$ & 7 & 9,0 & 4 & 10,8 & 3 & 7,3 \\
\hline & $\begin{array}{l}\text { licencjat/ } \\
\text { bachelor }\end{array}$ & 30 & 38,5 & 11 & 29,7 & 19 & 46,3 \\
\hline & $\begin{array}{c}\text { wyższe/ } \\
\text { high school }\end{array}$ & 12 & 15,4 & 4 & 10,8 & 8 & 19,5 \\
\hline
\end{tabular}




\begin{tabular}{|c|c|c|c|c|c|c|c|}
\hline $\begin{array}{c}\text { Miejsce } \\
\text { zamieszka- } \\
\text { nia/ } \\
\text { Place of } \\
\text { residence }\end{array}$ & $\begin{array}{c}\text { wieś/ } \\
\text { rural area } \\
\text { miasto/ } \\
\text { urban area }\end{array}$ & 53 & 67,9 & 22 & 59,5 & 31 & 75,6 \\
\hline \multirow{3}{*}{$\begin{array}{c}\text { Rodzaj } \\
\text { wykonywanej } \\
\text { pracy/ } \\
\text { Type of work }\end{array}$} & $\begin{array}{l}\text { umysłowa/ } \\
\text { intellectual }\end{array}$ & 20 & 25,7 & 5 & 13,5 & 15 & 36,6 \\
\hline & $\begin{array}{l}\text { fizyczna/ } \\
\text { physical }\end{array}$ & 37 & 47,4 & 21 & 56,8 & 16 & 39,0 \\
\hline & $\begin{array}{c}\text { bezrobocie/renta/emery- } \\
\text { tura/unemployment/ } \\
\text { annuity/retiring }\end{array}$ & 21 & 26,9 & 11 & 29,7 & 10 & 24,4 \\
\hline \multirow{5}{*}{ BMI } & $\begin{array}{c}\text { niedowaga/ } \\
\text { undernutrition }\end{array}$ & 1 & 1,3 & 0 & - & 1 & 2,6 \\
\hline & $\begin{array}{c}\text { prawidłowa masa ciała/ } \\
\text { normal weight }\end{array}$ & 28 & 35,9 & 11 & 29,7 & 17 & 43,6 \\
\hline & $\begin{array}{l}\text { nadwaga/ } \\
\text { overweight }\end{array}$ & 33 & 42,3 & 22 & 59,5 & 11 & 28,2 \\
\hline & $\begin{array}{l}\text { otyłość I stopnia/ } \\
\text { obesity 1. grade }\end{array}$ & 12 & 15,4 & 3 & 8,1 & 9 & 23,1 \\
\hline & $\begin{array}{l}\text { otyłość II stopnia/ } \\
\text { obesity 2. grade }\end{array}$ & 2 & 2,5 & 1 & 2,7 & 1 & 2,6 \\
\hline
\end{tabular}

Źródło: badanie własne

Source: authors' study

Do realizacji niniejszej pracy zastosowano metodę sondażu diagnostycznego, technikę ankiety. Narzędziem badawczym był kwestionariusz ankiety własnego autorstwa. Ankieta składała się z metryczki oraz części zasadniczej. Pytania zawarte w metryczce wymagały od badanych podania: płci, wieku, stanu cywilnego, rodzaju wykształcenia, miejsca zamieszkania, rodzaju wykonywanej pracy, wagi i wzrostu. Część zasadnicza ankiety zawierała 18 pytań dotyczących wybranych aspektów wiedzy badanych na temat samoopieki, samooceny tej wiedzy, a także obaw i oczekiwań związanych z zabiegiem operacyjnym.

Dane uzyskane w badaniu poddano analizie statystycznej z użyciem programu Statistica 10.0. Do opisu badanej grupy wykorzystano liczebności i odsetki osób, które charakteryzowały się daną cechą. Cechy ilościowe przedstawiono w postaci średniej arytmetycznej i odchylenia standardowego. W ocenie różnic pomiędzy grupami posłużono się testem nieparametrycznym U Manna-Whitneya dla prób niepowiązanych (brak rozkładu normalnego) oraz testem t-Studenta (rozkład normalny). W celu zbadania siły związku pomiędzy poszczególnymi zmiennymi losowymi zastosowano współczynnik korelacji tau Kendalla. W przypadku badania poziomu wiedzy ze względu na rodzaj wykonywanej pracy zastosowano odpowiednio test Kruskala-Wallisa i analizę wariancji. Do oceny poziomu wiedzy (zmienne nominalne) ze względu na dane z metryczki: płeć, stan cywilny, wykształcenie, rodzaj wykonywanej pracy, miejsce zamieszkania zastosowano test chi-kwadrat i test chi-kwadrat z poprawką Yatesa.

\section{Wyniki}

Zdecydowana większość badanych operowana była po raz pierwszy (92,3\%). W czasie badania średnio byli oni w 3,68 $\pm 1,52$ doby po zabiegu (1.-7. doba). Analiza danych uzyskanych w badaniu własnym wykazała, że zdecydowana większość badanych otrzymała informacje na temat samoopieki po zabiegu (78,2\%); 15,4\% badanych nie otrzymało żadnych informacji, natomiast 6,4\% nie pamięta przekazu takiej wiadomości.

Badanych, którzy potwierdzili fakt otrzymania informacji na temat samoopieki, poproszono o wskazanie, od kogo ją otrzymali (badani mogli zaznaczyć kilka odpowiedzi). Źródła informacji przedstawiono na rycinie 1.

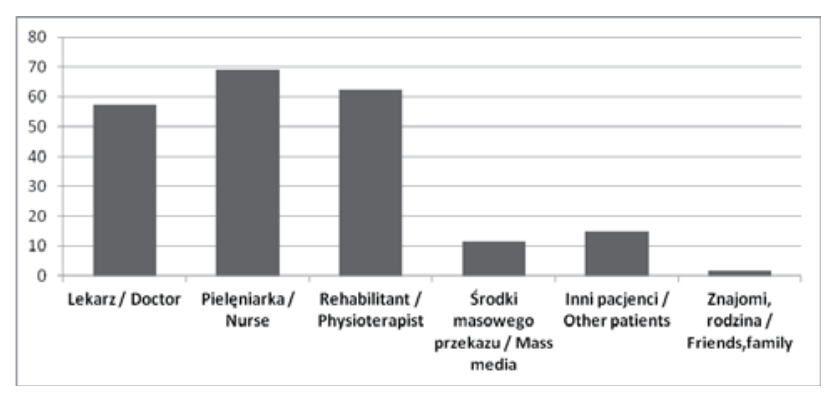

Rycina 1. Źródła uzyskanych informacji na temat samoopieki Figure 1. Sources of information about self-care

Źródło: opracowanie własne

Source: author's own analysis

Analiza czasu, w jakim badani otrzymali informacje na temat samoopieki, wykazała, że większość z nich $(75,4 \%)$ otrzymała je po zabiegu operacyjnym; $47,5 \%$ ankietowanych otrzymało takie informacje przed zabiegiem; co mniej więcej piąty badany otrzymał je przy wypisie do domu i w momencie rozpoznania choroby.

Samoocena poziomu wiedzy na temat samoopieki wykazała, że większość badanych raczej wie $(48,7 \%)$ lub nawet bardzo dobrze wie (28,2\%), co ma robić, aby ustrzec się nawrotu choroby. Odpowiedź „trudno powiedzieć" zaznaczyło 12,8\% ankietowanych; 7,7\% badanych raczej nie wie, co robić i czego unikać, a 2,6\% w ogóle nie posiada na temat samoopieki żadnych informacji. Analiza statystyczna wykazała istotną statystycznie zależność między samooceną poziomu wiedzy w zakresie samoopieki a wskaźnikiem BMI ( $p=0,010$; $\tau=0,20)$. Im wyższa wartość wskaźnika BMI, tym niższa samoocena wiedzy w zakresie, co robić i czego się wystrzegać, aby uniknąć wystąpienia objawów dyskopatii lędźwiowej.

Analiza wyników badania własnego wykazała, że prawie połowa badanych uważała, że ich wiedza jest raczej $(48,7 \%)$ lub zdecydowanie $(20,5 \%)$ wystarczająca. Odpowiedź „trudno powiedzieć” zaznaczyło 17,9\% 
z badanych; 11,5\% ankietowanych twierdziło, że ich wiedza jest raczej niewystarczająca, natomiast niewielki odsetek respondentów (1,3\%) uważał, że posiadana przez nich wiedza jest zdecydowanie niewystarczająca. Analiza statystyczna wykazała istotną statystycznie zależność między subiektywną oceną poziomu wiedzy a wskaźnikiem BMI ( $p=0,013 ; \tau=0,19)$. Im wyższa wartość wskaźnika BMI, tym niższy poziom subiektywnej oceny wiedzy w zakresie samoopieki w dyskopatii lędźwiowej. Badanym zadano pytanie: „Które z wymienionych czynności są dla Pana/i utrudnieniem po operacji?". W zakresie odpowiedzi mogli oni wybrać: wstanie z łóżka, długie stanie, chodzenie po korytarzu, chodzenie po schodach, inne i żadne. Opierając się na uzyskanych wynikach, można stwierdzić, że największy problem dla 64,1\% badanych stanowiło wstawanie z łóżka; drugim co do częstości wskazanym przez ankietowanych utrudnieniem było długotrwałe utrzymanie pozycji stojącej; $37,2 \%$ badanych wskazało na problem z chodzeniem po schodach; dla 9\% respondentów uciążliwe było chodzenie po korytarzu, odpowiedź „inne” zaznaczyło 7,7\% ankietowanych i wymieniło położenie się do łóżka. Natomiast tylko 0,5\% respondentów nie zgłaszało żadnych z wymienionych w ankiecie utrudnień.

\section{Analiza poziomu wiedzy na temat zachowań niewskazanych po zabiegu operacyjnym}

Zdecydowana większość badanych (75,6\%) była świadoma, jaka jest maksymalnie dozwolona waga podnoszonych przedmiotów (wyjątkowo 2-5 kg) i tylko nieliczni $(21,8 \%)$ podali w tym zakresie błędną odpowiedź. Analiza statystyczna wykazała istotną statystycznie zależność pomiędzy znajomością dopuszczalnej wagi podnoszonych przedmiotów a płcią badanych ( $p=0,018$ ). Prawidłową znajomością dopuszczalnej wagi podnoszonych przedmiotów wykazało się istotnie więcej badanych kobiet $(87,8 \%)$ w stosunku do badanych mężczyzn (62,2\%). Stwierdzono także, że badani, którzy poprawnie odpowiedzieli na to pytanie, częściej w opisanej wcześniej samoocenie wiedzy potwierdzali wystarczający jej poziom ( $p=0,002)$.

Analiza wyników badania własnego w zakresie odpowiedzi na pytanie: „Czy zgodnie z Pana/i wiedzą ważna jest pozycja przyjmowana przy podnoszeniu przedmiotów?" wykazała, że 72,7\% ankietowanych udzieliło prawidłowej odpowiedzi („zdecydowanie tak”), natomiast pozostała część badanych udzieliła w tym zakresie odpowiedzi nieprawidłowych. Prawie wszyscy badani $(98,6 \%)$ prawidłowo także określili pozycję wymaganą przy podnoszeniu przedmiotów jako „na ugiętych nogach"; niewielki odsetek ankietowanych $(1,4 \%)$ udzielił błędnej odpowiedzi. Natomiast żaden z respondentów nie zaznaczył odpowiedzi, że każda pozycja jest prawidłowa. Wiedzę ankietowanych na temat zachowań niewskazanych po zabiegu operacyjnym przedstawia tabela 2.

Tabela 2. Wiedza badanych na temat zachowań niewskazanych po zabiegu operacyjnym z uwzględnieniem płci

Table 2. Knowledge of respondents about the behaviors not recommended after surgery by sex

\begin{tabular}{|c|c|c|c|c|c|c|}
\hline \multirow{3}{*}{$\begin{array}{l}\text { Jakie, zgodnie z Pana/i wiedza, } \\
\text { zachowania są niewskazane po za- } \\
\text { biegu operacyjnym?/What behaviors, } \\
\text { according to your knowledge, are not } \\
\text { recommended after surgery? }\end{array}$} & \multirow{2}{*}{\multicolumn{2}{|c|}{$\begin{array}{l}\text { Ogółem/ } \\
\text { Total } \\
\mathrm{N}=78\end{array}$}} & \multicolumn{4}{|c|}{ Płeć/Sex } \\
\hline & & & \multicolumn{2}{|c|}{$\begin{array}{l}\text { mężczyźni/ } \\
\text { males } \\
\mathrm{N}=37\end{array}$} & \multicolumn{2}{|c|}{$\begin{array}{c}\text { kobiety/ } \\
\text { females } \\
\mathrm{N}=41\end{array}$} \\
\hline & $\mathrm{n}$ & $\%$ & $\mathrm{n}$ & $\%$ & $\mathrm{n}$ & $\%$ \\
\hline $\begin{array}{l}\text { Trwanie zbyt długo w jednej pozycji, } \\
\text { np. stanie/Being for too long in one } \\
\text { position, e.g. standing }\end{array}$ & 37 & 47,4 & 19 & 51,4 & 18 & 43,9 \\
\hline Schylanie się/Bending down & 64 & 82,1 & 29 & 78,4 & 35 & 85,4 \\
\hline $\begin{array}{l}\text { Chodzenie na obcasach/ } \\
\text { Walking on heels }\end{array}$ & 48 & 61,5 & 14 & 37,8 & 34 & 82,9 \\
\hline $\begin{array}{c}\text { Siadanie z nogami wyciągniętymi } \\
\text { przed siebie/Sitting down with legs } \\
\text { stretched out forward }\end{array}$ & 25 & 32,1 & 13 & 34,1 & 12 & 29,3 \\
\hline $\begin{array}{l}\text { Zakładanie nogi na nogę/ } \\
\text { Sitting with the legs crossed }\end{array}$ & 40 & 51,3 & 18 & 48,7 & 22 & 53,7 \\
\hline Inne/Other & 1 & 1,3 & 0 & - & 1 & 2,4 \\
\hline Nie wiem/Don't know & 5 & 6,5 & 4 & 10,8 & 1 & 2,4 \\
\hline
\end{tabular}

Inne: szybkie wstawanie z łóżka/Other: getting out of bed quickly

Źródło: badanie własne

Source: authors' study

Za pomocą testu U Manna-Whitneya zbadano różnice w poziomie znajomości wszystkich zachowań, które są niewskazane po zabiegu operacyjnym, ze względu na wykształcenie. Ze względu na małą liczebność dla potrzeb analizy połączono badanych w dwie kategorie: „wykształcenie podstawowe i zawodowe” oraz „wykształcenie średnie i wyższe”. Analiza statystyczna wykazała, że osoby ze średnim i wyższym wykształceniem miały większą wiedzę w zakresie zachowań, które są niewskazane po zabiegu operacyjnym, niż badani $z$ wykształceniem podstawowym i zawodowym $(p=0,039)$. Badani z wykształceniem średnim i wyższym podawali średnio trzy z pięciu prawidłowych odpowiedzi, a z wykształceniem podstawowym i zawodowym wskazywali przeciętnie o jedną mniej.

Oceniając wiedzę badanych, pytano ich także, jak ważne jest utrzymanie prawidłowej masy ciała, aby uniknąć wystąpienia powikłań po zabiegu operacyjnym. Ponad połowa badanych $(56,4 \%)$ uznała zdecydowaną ważność utrzymania prawidłowej wagi ciała, natomiast pozostała część z nich udzieliła odpowiedzi kwalifikowanych jako nieprawidłowe. Szczegółowa analiza statystyczna z użyciem testu t-Studenta wykazała, że badani w 4. dobie po operacji istotnie częściej prawidłowo odpowiadali na to pytanie, w porównaniu do badanych 
$w$ innych dobach po operacji $(p=0,023)$. Analiza statystyczna wykazała także istotną statystycznie różnice w odpowiedzi na wyżej opisane pytanie, za względu na subiektywną ocenę poziomu wiedzy. Badani, którzy odpowiadali poprawnie na to pytanie, twierdzili istotnie częściej, że mają wystarczającą wiedzę w zakresie samoopieki, w porównaniu do badanych, którzy udzielali nieprawidłowej odpowiedzi ( $p<0,001)$.

Analiza wiedzy badanych na temat pożądanej po zabiegu operacyjnym aktywności fizycznej wykazała, że zdecydowana większość z nich wskazała prawidłowe odpowiedzi, którymi były: spacery na świeżym powietrzu, po płaskim terenie $(94,9 \%)$ i pływanie $(62,8 \%)$. W badanej grupie 11,5\% respondentów zaznaczyło „marsz, bieganie po płaskim terenie”; 3,9\% ankietowanych nie potrafiło wybrać żadnej aktywności fizycznej; 2,6\% badanych uważało, że każda aktywność jest niewskazana. Natomiast 1,3\% ankietowanych z podanych aktywności fizycznych zaznaczyło piłkę nożną, siatkową i ręczną. Za pomocą współczynnika tau Kendalla zbadano zależność między poziomem znajomości aktywności fizycznej wskazanej po operacji a subiektywną oceną wiedzy na temat samoopieki. Analiza statystyczna wykazała ujemną, słabą, ale istotną statystycznie zależność między tymi zmiennymi. Badani, którzy częściej wybierali nieprawidłową odpowiedź w zakresie aktywności fizycznej wskazanej po operacji, istotnie także częściej oceniali swój poziom wiedzy na temat samoopieki jako niewystarczający $(p=0,001 ; \tau=-0,26)$.

Analizę wyników badania własnego w obszarze zaleceń dotyczących snu i odpoczynku przedstawia tabela 3.

Tabela 3. Wiedza badanych na temat zaleceń dotyczących snu i wypoczynku po zabiegu operacyjnym z uwzględnieniem płci Table 3. Knowledge of respondents about the recommendations for sleep and rest after surgery by sex

\begin{tabular}{|c|c|c|c|c|c|c|}
\hline \multirow{3}{*}{$\begin{array}{l}\text { Jakie, zgodnie z Pana/i wiedzą, } \\
\text { zalecenia dotyczą snu i odpo- } \\
\text { czynku?/What, according to your } \\
\text { knowledge, are recommendations } \\
\text { for sleep and rest after surgery }\end{array}$} & \multirow{2}{*}{\multicolumn{2}{|c|}{$\begin{array}{l}\text { Ogółem/ } \\
\text { Total } \\
\mathrm{N}=78\end{array}$}} & \multicolumn{4}{|c|}{ Płeć/Sex } \\
\hline & & & \multicolumn{2}{|c|}{$\begin{array}{l}\text { mężczyźni/ } \\
\text { males } \\
\mathrm{N}=37\end{array}$} & \multicolumn{2}{|c|}{$\begin{array}{l}\text { kobiety/ } \\
\text { females } \\
\mathrm{N}=41\end{array}$} \\
\hline & $\mathrm{n}$ & $\%$ & $\mathrm{n}$ & $\%$ & $\mathrm{n}$ & $\%$ \\
\hline $\begin{array}{l}\text { Leżenie na miękkim materacu/ } \\
\text { Lying on a soft mattress }\end{array}$ & 8 & 10,3 & 4 & 10,8 & 4 & 9,8 \\
\hline $\begin{array}{l}\text { Unikanie grubych, dużych podu- } \\
\text { szek pod głowę/Avoiding thick, } \\
\text { large pillows under a head }\end{array}$ & 55 & 70,5 & 22 & 59,46 & 33 & 80,49 \\
\hline $\begin{array}{l}\text { Leżenie na plecach/ } \\
\text { Supine position }\end{array}$ & 32 & 41,0 & 17 & 45,95 & 15 & 36,59 \\
\hline $\begin{array}{l}\text { Leżenie na zdrowym boku z lekko } \\
\text { ugiętymi nogami/Lying on the heal- } \\
\text { thy side with slightly bent legs }\end{array}$ & 41 & 52,6 & 17 & 45,95 & 24 & 58,54 \\
\hline Nie wiem/Don't know & 8 & 10,3 & 5 & 13,51 & 3 & 7,32 \\
\hline
\end{tabular}

Źródło: badanie własne

Source: authors' study
Za pomocą współczynnika tau Kendalla zbadano zależność między poziomem wiedzy w zakresie pytania: „Jakie zalecenia dotyczą snu i odpoczynku?” a subiektywną oceną wiedzy na temat samoopieki. Analiza statystyczna wykazała ujemną, o przeciętnym nasileniu, bardzo istotną statystycznie zależność między tymi zmiennymi ( $p<0,0001 ; \tau=-0,321)$. Im samoocena badanych wskazywała na bardziej niewystarczającą wiedzę, tym poziom ich wiedzy w zakresie pytania: „Jakie zalecenia dotyczą snu i odpoczynku?" był niższy.

Na podstawie analizy wszystkich pytań dotyczących wiedzy i szczegółowej analizy możliwych odpowiedzi prawidłowych (14) dokonano oceny wiedzy ogółem. Za każdą odpowiedź prawidłową przydzielono 1 pkt. Badani udzielali średnio $7 \pm 2$ prawidłowych odpowiedzi (1-12 prawidłowych odpowiedzi). Analiza istotności statystycznych na poziomie 0,05 wykazała, że wiedza ogółem istotnie była zdeterminowana przez zmienne: „rodzaj wykonywanej pracy” oraz „subiektywna ocena wiedzy badanych na temat samoopieki". Okazało się, że pracujący fizycznie mieli istotnie niższą wiedzę ogółem niż pracujący umysłowo oraz będący na bezrobociu/rencie/emeryturze ( $p=0,019)$. Analizę powyższą przedstawia tabela 4.

Tabela 4. Charakterystyka różnic w poziomie wiedzy ogółem z uwzględnieniem rodzaju wykonywanej pracy

Table 4. Characteristic differences in the level of general knowledge by type of work

\begin{tabular}{cccccc}
\hline $\begin{array}{c}\text { Rodzaj wykonywanej pracy/ } \\
\text { Type of work }\end{array}$ & \multicolumn{5}{c}{$\begin{array}{c}\text { Wiedza ogółem/ } \\
\text { General knowledge }\end{array}$} \\
\cline { 2 - 6 } & $\begin{array}{c}\text { Średnia// } \\
\text { Mean }\end{array}$ & SD & Min. Maks. p-value \\
\hline $\begin{array}{c}\text { Umysłowa/ } \\
\text { Intellectual }\end{array}$ & 8,05 & 1,85 & 5,00 & 11,00 \\
$\begin{array}{c}\text { Fizyczna/Physical } \\
\text { Bezrobocie/renta/merytura/Unem- } \\
\text { ployment/annuity/retiring }\end{array}$ & 6,46 & 2,78 & 1,00 & 12,00 & $0,019^{*}$ \\
\hline
\end{tabular}

SD - odchylenie standardowe/standard deviation; Min. - minimum/ minimum; Maks. - maksimum/maximum; *ANOVA

Źródło: badanie własne

Source: authors' study

Badani lepiej oceniający swój poziom wiedzy na temat samoopieki udzielali statystycznie istotnie więcej prawidłowych odpowiedzi w zakresie wiedzy ogólnej $(p<0,0001)$. Nie wykazano natomiast istotnego związku pomiędzy wiedzą ogółem a innymi zmiennymi socjodemograficznymi, ani też okresem, jaki minął po zabiegu, czy faktem przebycia takiej samej operacji wcześniej $(p>0,05)$. 


\section{Analiza obaw i oczekiwań związanych z zabiegiem operacyjnym}

Opierając się na uzyskanych wynikach dotyczących obaw badanych, można stwierdzić, że prawie połowa respondentów $(49,4 \%)$ potwierdza występowanie lęku i obaw; $28,6 \%$ ankietowanych nie potrafiło odpowiedzieć na to pytanie, a tylko 22,1\% badanych negowato ich pojawienie się. Analiza statystyczna wykazała istotną statystycznie zależność między tymi zmiennymi, wykształceniem a zgłaszaniem obaw ( $p<0,001)$. Istnienie obaw potwierdziło zdecydowanie mniej badanych z wykształceniem średnim i wyższym $(63,3 \%)$ w stosunku do jedynie $25 \%$ badanych z wykształceniem podstawowym i zawodowym. Z kolei badanym z niższym wykształceniem trudniej było odpowiedzieć na pytanie o obawy związane z powrotem do domu $(53,6 \%)$. Konkretne sytuacje, które budzą niepokój badanych, przedstawia rycina 2.

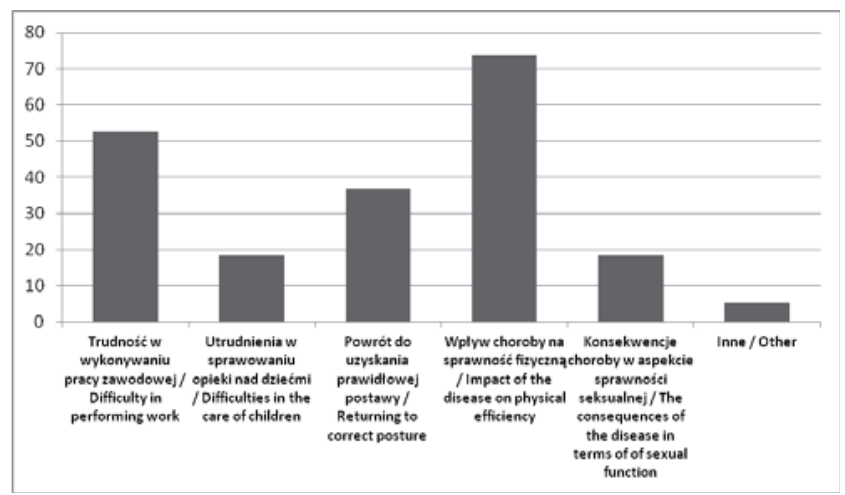

Inne: poczucie zależności od osób trzecich/

Other: sense of depending on others

Rycina 2. Sytuacje, które budzą niepokój badanych Figure 2. Situations that raise concern of respondents

Źródło: opracowanie własne

Source: author's own analysis

Analiza statystyczna wykazała istotną statystycznie zależność między zmienną „trudności w dalszym wykonywaniu pracy zawodowej" a rodzajem wykonywanej pracy. W badanej grupie 83,3\% respondentów wykonujących pracę fizyczną miało większe obawy w tym zakresie niż badani wykonujący pracę umysłową bądź bezrobotni/renciści/emeryci $(p<0,001)$. Analiza pytania o oczekiwaną poprawę stanu zdrowia wykazała, iż „zdecydowanie zadowolonych” badanych było 38,5\%; żaden z badanych nie negował poprawy stanu zdrowia, jedynie co mniej więcej trzeci badany nie potrafił określić swojego poziomu satysfakcji, co wynikało z faktu, że pytanie to zadano mu w zbyt wczesnej dobie po zabiegu operacyjnym.

\section{Dyskusja}

Dyskopatia lędźwiowa to choroba przewlekła, która może być powodem wielu dodatkowych schorzeń, a nawet trwałego kalectwa. Występuje najczęściej bez związku z płcią, choć znane są czynniki zawodowe usposabiające do jej pojawienia się. Leczenie jej jest często długotrwałe i nierzadko wiąże się z koniecznością przeprowadzenia zabiegu operacyjnego [4, 17-19].

Rozwój pielęgniarstwa poszerzył funkcje zawodowe pielęgniarki o funkcję edukacyjną. Wg Ciechaniewicz [20] edukacja to „proces celowych oddziaływań wychowawczych i dydaktycznych, w którym rolę nauczycieli powinni pełnić różni profesjonaliści, (...) zgodnie z posiadanymi kompetencjami w zakresie osiągania celów edukacji i realizacji zaplanowanych treści”. Ze względu na fakt, że zdecydowana większość badanych (92\%) poddała się operacji dyskopatii lędźwiowej po raz pierwszy, istotne wydaje się być wyposażenie ich w odpowiedni poziom wiedzy na temat zachowań prozdrowotnych po zabiegu operacyjnym. Umiejętnie prowadzona edukacja i wyeliminowanie czynników, które mogą spowodować nawrót choroby, są niepodważalnymi składowymi prowadzącymi do tego celu. Jednym z podstawowych elementów profilaktyki wtórnej jest znajomość pozycji zalecanej przy podnoszeniu przedmiotów. Z badań własnych wynika, że zdecydowana większość ankietowanych wiedziała, że znajomość tej pozycji jest bardzo ważna i prawie wszyscy umieli ją wskazać. Natomiast odmienne rezultaty prezentują Zub i wsp. [21]. Podają oni mianowicie, że jedynie $41 \%$ badanych znało zasady, które obowiązuja przy podnoszeniu przedmiotów. Przeszkodą w przyjęciu prawidłowej postawy ciała może okazać się często występująca u pacjentów nadwaga i otyłość (około 2/3 badanych miało BMI powyżej normy). Świadomość pacjentów dotycząca wpływu odpowiednio zbilansowanej diety, ograniczającej tłuszcze, cukry proste, oraz utrzymania prawidłowej wagi ciała na pozytywny przebieg rekonwalescencji jest niezmiernie istotna. W przypadku dyskopatii największym problemem wydaje się być występowanie przewlekłych dolegliwości bólowych, które - obniżając sprawność fizyczną - znacząco wpływają na narastającą niechęć do ruchu, czego skutkiem może być właśnie otyłość.

Ważnym elementem współczesnego pielęgniarstwa, ale i medycyny w ogóle, jest określenie poziomu satysfakcji pacjentów ze świadczonych usług. Elementy opieki pielęgniarskiej wpływające na zadowolenie pacjenta obejmują między innymi kompetencje pielęgniarek w zakresie wyposażenia pacjentów w odpowiedni poziom wiedzy, rozpraszania ich obaw i niepewności $[22,23]$. Pacjenci w badaniu niniejszym czerpali wiedzę 
na temat samoopieki z wielu źródeł. Pozytywnym wynikiem jest to, że wiadomości te pochodziły najczęściej od wykwalifikowanego personelu medycznego, a więc pielęgniarki, lekarza czy rehabilitanta zatrudnionego na oddziale neurochirurgicznym. Wyniki badania własnego potwierdzają również, że wiedza ogólna badanych nie jest wystarczająca. Pacjenci dawali temu wyraz, udzielając często nieprawidłowych odpowiedzi na niektóre pytania, ale także wyrażając w samoocenie swoje przekonanie o niedostatkach tej wiedzy i niepewności z tym związanej. Można przypuszczać, że głównym powodem takiego stanu rzeczy był fakt, iż edukacja była najczęściej prowadzona dopiero po zabiegu operacyjnym, co potwierdziło $75 \%$ ankietowanych. Tymczasem już w ramach profilaktyki pierwszo- i drugorzędowej można byłoby ludzi wyuczyć zachowań w życiu codziennym, które skutecznie odciążą kręgosłup. Interesującą propozycją wydaje się na przykład być edukacja prowadzona w tzw. szkole pleców, metodzie znanej już od 1950 roku [21].

Jednym z obszarów poddanych analizie w badaniu własnym była ocena obaw respondentów związanych z funkcjonowaniem po zabiegu operacyjnym. Przeprowadzone badania potwierdziły, że wpływ na obawy pacjentów ma wykształcenie; okazało się podobnie jak w pracy Turkiewicz-Maligrandy [12], iż osoby ze średnim i wyższym wykształceniem są bardziej świadome swojego stanu i ponad połowa z nich odczuwa lęk przed powrotem do domu. Otrzymane wyniki wskazują na to, że strach przed trudnościami w dalszym wykonywaniu pracy zawodowej i wpływem choroby na sprawność fizyczną jest dominujący. Wydaje się, że niemały wpływ na to mógł mieć również fakt, iż większość badanych stanowiły osoby pracujące fizycznie. Należy w tym miejscu zaznaczyć, że obawy i braki w świadomości prawidłowej samoopieki, które zgłaszali ankietowani pacjenci, mogą wynikać przede wszystkim z krótkiego czasu pobytu na oddziale po zabiegu operacyjnym. Wiadomo, iż każdy kolejny dzień rekonwalescencji wzbogaca wiedzę pacjenta i podnosi poczucie pewności siebie, a co za tym idzie - wspomaga szybki i efektywny powrót do pełnej sprawności [24]. Niestety ze względu na wysokie koszty hospitalizacji czas pobytu pacjenta po zabiegu operacyjnym skracany jest obecnie w placówkach leczniczych do minimum.

Podsumowując, można stwierdzić, że podniesienie świadomości zdrowotnej należy oprzeć na szeroko rozpropagowanej profilaktyce, zarówno pierwotnej, jak i wtórnej, edukacji społeczeństwa na temat przyczyn dolegliwości bólowych kręgosłupa oraz sposobów radzenia sobie z następstwami choroby. Działania edukacyjne powinny przygotować pacjenta do samoopieki i podjęcia współodpowiedzialności za swoje zdrowie [6, 21, 25]. Zdrowie jest wartością nadrzędną, a wiedza, jak o nie dbać, to obowiązek każdego człowieka.

\section{Piśmiennictwo}

1. Stan zdrowia ludności Polski w 2014 r. Warszawa: GUS, http://stat.gov.pl/obszary-tematyczne/zdrowie/zdrowie/stan -zdrowia-ludnosci-polski-w-2014-r-,6,6.html (data dostępu: 10.08.2016).

2. Kułak W, Kondzior D. Dyskopatia kręgosłupa odcinka lędźwiowo-krzyżowego w korelacji z natężeniem bólu, depresją i akceptacją choroby. Probl Hig Epidemiol. 2010; 91(1): 153-157.

3. Radziszewski K. Analiza porównawcza aktywności zawodowej pacjentów z dyskopatią lędźwiową leczonych wyłącznie zachowawczo bądź operowanych. Wiad Lek. 2007; 60: 15-21.

4. Sajdak B, Bodys-Cupak I. Ocena wyników operacyjnego leczenia dyskopatii w zależności od stopnia nasilenia dolegliwości bólowych. Pol Prz Nauk Zdr. 2014; 3(40): 216-222.

5. Pytel A, Wrzosek Z. Standard opieki pielęgniarskiej nad chorym z dyskopatią lędźwiowo-krzyżową kręgosłupa jako wyznacznik wysokiej jakości świadczeń medycznych. Kwart Ortop. 2009; 3: 339-345.

6. Klimaszewska K, Krajewska-Kułak E, Kondzior D, Kowalczuk K, Jankowiak B. Jakość życia pacjentów z zespołami bólowymi odcinka lędźwiowego kręgosłupa. Probl Piel. 2011; 19(1): 47-54.

7. Sipko T, Chantsoulis-Supińska M, Żmuda M, Zwoliński J. Zrównoważenie postawy ciała u pacjentów z chorobą dyskową we wczesnym okresie pooperacyjnym. Ortop Traumatol Rehabil. 2008; 10(3): 226-237.

8. Antczak A, Haor B, Głowacka M, Biercewicz M. The role of the nurse in the treatment of back pain. J Neurol Neurosurg Nurs. 2014; 3(1): 39-43.

9. Haładyna W, Marciniszyn E, Kuliński W. Dyskopatie kręgosłupa - aktualny problem diagnostyczny i terapeutyczny. Acta Balneol. 2011; 53(2): 133-137.

10. Binek E, Olszewski J. Ocena dolegliwości bólowych u chorych z dyskopatią lędźwiową przed i po wybranych zabiegach fizjoterapeutycznych. Kwart Ortop. 2011; 2: 93-99.

11. Hoffman J, Dejewska I, Stępowska J, Hagner W. Wpływ rehabilitacji na wynik leczenia operacyjnego dyskopatii odcinka lędźwiowo-krzyżowego. Kwart Ortop. 2009; 2: 156-161.

12. Turkiewicz-Maligranda A. Psychosocjologiczne uwarunkowania przeciwdziałania niepełnosprawności chorych w wieku produkcyjnym wynikającej z choroby dyskowej odcinka krzyżowo-lędźwiowego kręgosłupa - przegląd literatury. Piel Zdr Publ. 2013; 3-4: 353-357.

13. Waliszewska R, Zieliński P. Wpływ wybranych czynników psychologicznych i socjalnych na chęć powrotu do aktywności zawodowej pacjentów po zabiegach dyskopatii lędźwiowej i szyjnej. Piel Neurol Neurochir. 2012; 1: 65-69.

14. Derewecki T, Duda M, Majcher P. Wpływ dyskopochodnych dolegliwości bólowych kręgosłupa L-S na postawę ciała. Doniesienie wstępne. Ortop Traumatol Rehabil. 2013; 15(1): 31-39.

15. Jabłońska R, Ślusarz R, Królikowska A, Beuth W, Ciemnoczołowski W. Uwarunkowania wydolności funkcjonalnej chorych we wczesnym okresie pooperacyjnym leczenia dyskopatii lędźwiowo-krzyżowej. Piel Chir Angiol. 2008; 4: 144-150.

16. Koszewski W. Leczenie zespołów bólowych kręgosłupa w przebiegu dyskopatii. Lek POZ. 2015; 1: 23-33.

17. Jabłońska R, Królikowska A, Dybciak G, Szynkiewicz E, Swincow A. The influence of surgical treatment on reported ailments and neurological status of patients with spine discopathy. J Neurol Neurosurg Nurs. 2015; 4(3): 109-116.

18. Kiwerski JE. Choroba dyskowa dolnego odcinka kręgosłupa u osób młodych. Post Rehabil. 2011; 25(1): 19-22. 
19. Ciesielska M, Nowacka K, Siedlecki Z, Winkler P, Beuth W, Józwiak G, Sasinowska M, Hagner W. Environmental factors of the intervertebral disc disorder in patients after surgical treatment of the cervical and lumbosacral discopathy. Med Biol Sci. 2010; 24/4: 13-17.

20. Ciechaniewicz W. Pedagogika. Warszawa: PZWL; 2008.

21. Zub W, Berny W, Tonderys-Rosińczuk J, Weiser A, Prudlak G. Poziom wiedzy pacjentów na temat dyskopatii lędźwiowej i profilaktyki bólów krzyża. W: Krajewska-Kułak E, Sierakowska M, Lewko J (red.). Pacjent przedmiotem troski zespołu terapeutycznego. Białystok: Wyd. AM w Białymstoku; 2005. 410-415.

22. Ślusarz R, Biercewicz M, Barczykowska E, Haor B, Głowacka M. Assessment of selected quality fields of nursing care in neurosurgical wards: a prospective study of 530 people - multicenter studies. Patient Prefer Adherence. 2014; 8: 1113-1121.

23. Garczyk D, Jankowski R, Misterska E, Głowacki M, Żukiel $R$, Kowalska AM. Patient satisfaction with nursing after surgery due to cervical or lumbar discopathy. Med Sci Monit. 2013; 19: 892-902.

24. Latacka K, Hagner W, Nowacka K, Grzelak L. Effectivenes of the rehabilitation process and return to professional activity in patients operated on due to cervical discopathy or lumbar discopathy. Med Biol Sci. 2010; 24/4: 27-32.
25. Garczyk D. Zadowolenie chorego jako wyraz jakości opieki pielęgniarskiej u pacjentów leczonych chirurgicznie z powodu dyskopatii w odcinku szyjnym lub lędźwiowym kręgosłupa. Piel Neurol Neurochir. 2013; 2(2): 48-56.

Artykuł przyjęty do redakcji: 28.10 .2016

Artykuł przyjęty do publikacji: 22.11.2016

Źródło finansowania: Praca nie jest finansowana z żadnego źródła. Konflikt interesów: Autorzy deklarują brak konfliktu interesów.

\section{Adres do korespondencji:}

Beata Babiarczyk

ul. Willowa 2

43-300 Bielsko-Biała

tel. kom.: 512276383

e-mail: bbabiarczyk@ath.bielsko.pl

Akademia Techniczno-Humanistyczna 